\title{
Pengaruh Inovasi Produk dan Orientasi Kewirausahaan Terhadap Kinerja Pemasaran (Studi Pada Industri Mikro Kecil Makanan di Kota Denpasar)
}

\author{
IA Cynthia Saisaria Mandasari \\ Faculty of Economic and Business, Universitas Warmadewa, Denpasar, Bali-Indonesia
}

cynthiafeunwar@gmail.com

\author{
How to cite (in APA style): \\ Mandasari, I, A.C.S. (2020). Pengaruh Inovasi Produk dan Orientasi Kewirausahaan Terhadap \\ Kinerja Pemasaran(Studi Pada Industri Mikro Kecil Makanan di Kota Denpasar). Warmadewa \\ Management and Business Joural, 2(2) pp.56-62
}

\begin{abstract}
The number of Micro Small Industries in Denpasar City has now increased. This causes increasingly fierce competition in the food industry sector in Denpasar City. Facing intense competition, entrepreneurs are required to always innovate in their products and support the entrepreneurial character in order to improve their marketing performance. The purpose of this research is to study conversation motivation and innovation towards marketing products.

This research was conducted in the city of Denpasar on the owners or managers of the food micro-small industry. The number of samples taken was 100 food business owners, using a non probability sampling method, specifically purposive sampling. Data collection was carried out through a questionnaire. The analysis technique used is path analysis.

Based on the results of the analysis of this study it was found that the variables that encourage entrepreneurship fully positively influence marketing performance. Improving communication skills can be done so it can improve marketing performance. Official partial product innovation has a significant positive effect on marketing performance. The more often entrepreneurs do product promotion, the more they will increase. Variables talk about entrepreneurship and innovation that are supported simultaneously and significantly to marketing performance. This shows that the better it is to increase entrepreneurship and to increasingly improve products that will increase the level of marketing in a company.
\end{abstract}

Keywords: communicating entrepreneurship, product innovation, marketing performance.

Abstrak

Jumlah Industri Mikro Kecil di Kota Denpasar saat ini telah mengalami peningkatan secara terus menerus. Hal ini menyebabkan persaingan semakin ketat dalam sector industri makanan di Kota Denpasar. Menghadapi ketatnya persaingan, para wirausahawan dituntut untuk selalu berinovasi dalam produknya serta memperkuat karakter kewirausahaan agar dapat meingkatkan kinerja pemasarannya. Tujuan penelitian ini adalah untuk mengetahui pengaruh orientasi kewirausahaan dan inovasi produk terhadap kinerja pemasaran.

Penelitian ini dilakukan di Kota Denpasar terhadap pemilik atau pengelola Industri Mikro Kecil makanan. Ukuran sampel yang diambil sebanyak 100 orang pemilik usaha makanan, dengan metode non probability sampling, khususnya purposive sampling. Pengumpulan data dilakukan melalui kuesioner. Teknik analisis yang digunakan adalah path analysis.

Berdasarkan hasil analisis penelitian ini ditemukan bahwa variabel orientasi kewirausahaan secara parsial berpengaruh positif signifikan terhadap kinerja pemasaran. Semakin baik orientasi kewirausahaan yang dilakukan maka dapat meningkatkan kinerja pemasaran. Inovasi produk secara parsial berpengaruh positif signifikan terhadap kinerja pemasaran. Semakin sering pengusaha melakukan inovasi produk mereka maka akan meningkatan kinerja pemasaran. Variabel orientasi kewirausahaan dan inovasi produk berpengaruh secara simultan dan signifikan terhadap kinerja pemasaran. Hal ini menunjukkan bahwa semakin baik kemampuan orientasi kewirausahaan dan semakin baik inovasi produk yang dilakukan akan semakin tinggi tingkat kinerja pemasaran pada suatu perusahaan.

Kata Kunci: orientasi kewirausahaan, inovasi produk, kinerja pemasaran. 


\section{PENDAHULUAN}

Teknologi informasi terus berkembang sangat pesat sehingga mempengaruhi perekonomian dunia, dimana perekonomian mengarah pada tingkat persaingan yang semakin tinggi pada era globalisasi yang kini tidak dapat dihindari bagi setiap kalangan industri. Industri memiliki jenis yang beragam mulai dari industri pakaian, makanan, minuman, mebel, dan furniture. Menurut (Kotler \& Keller., 2008), industri merupakan sekelompok perusahaan yang menawarkan suatu produk atau kelas produk yang merupakan subtitusi dekat antara satu dengan lainnya.

Berdasarkan sensus ekonomi yang dilakukan Badan Pusat Statistik Provinsi Bali, jumlah Industri Mikro Kecil di provinsi Bali pada tahun 2016 adalah sebanyak 468.658 unit lebih mendominasi dibandingkan jumlah Industri Mikro Besar yakni sebanyak 13.826 unit dan jumlah Industri mikro kecil terbanyak terdapat di Kota Denpasar yang merupakan Ibukota Provinsi Bali, yang menyumbang 93.009 unit usaha mikro kecil, hal ini membuktikan bahwa usaha pada sektor mikro kecil sangat diminati oleh wirausahawan di Provinsi Bali, khususnya Kota Denpasar.

Industri yang paling banyak dan mudah ditemui adalah industri makanan. Usaha bidang makanan dianggap cukup menjanjikan, hal ini disebabkan makanan merupakan kebutuhan sehari-hari yang kerap dikonsumsi pelanggan, serta usaha di sektor industri makanan ini tidak membutuhkan investasi yang tinggi dalam pengelolaannya. Meningkatnya jumlah usaha pada sektor makanan mampu meningkatkan perekonomian suatu daerah serta menyebabkan ketatnya persaingan yang dihadapi oleh wirausahawan. Menurut data BPS pada tahun 2015, sebanyak 1.567.019 unit usaha mikro kecil yang bergerak pada sektor industri makanan di Indonesia.

Selain meningkatkan perekonomian, meningkatnya jumlah Industri Mikro Kecil telah meningkatkan pula persaingan diantara usaha-usaha di sektor industri makanan. Selain masalah dalam persaingan usaha, Industri Mikro Kecil umumnya memiliki kelemahan diantaranya, Industri Mikro Kecil umumnya merupakan usaha milik keluarga, penggunaan teknologi yang masih relatif sederhana, kurang memiliki akses permodalan, dan tidak ada pemisah antara modal usaha dengan kebutuhan pribadi (Sudaryanto, et.al, 2013)

Dengan banyaknya usaha-usaha dalam sektor makanan serta banyaknya usaha baru yang bermunculan menyebabkan persaingan semakin ketat, perubahan yang terjadi dalam persaingan telah menciptakan perubahan dalam hal kebutuhan pelanggan, pengelolaan produk serta pangsa pasar (Djojobo \& Tawas, 2014). Menurut Alarape, (2013), cara terbaik untuk meningkatkan penjualan serta memenangkan persaingan konsumen industry mikro kecil adalah dengan meningkatkan tiga dimensi utama orientasi kewirausahaan diantaranya inovatif, proaktif dan berani mengambil risiko.

Menghadapi persaingan dalam sektor industri makanan, pemilik usaha haruslah memiliki keunikan dan keunggulan dibandingkan produk pesaing sejenis dengan cara berinovasi terhadap produknya. Inovatif merupakan sikap dari seorang wirausahawan (entrepreneur) yang mengacu pada suatu sikap wirausahawan untuk terlibat secara kreatif dalam proses percobaan terhadap gagasan baru yang memungkinkan wirausahawan menghasilkan produk atau jasa baru, baik untuk pasar sekarang maupun ke pasar baru (Wardoyo, 2015).

Wirausahawan merupakan seorang yang kreatif yang memiliki kemampuan dan keuletan dalam mengembangkan ide-ide baru dengan cara menggabungkan sumber-sumber daya yang dimiliki untuk selalu menganalisa situasi dan permasalahan sebelumnya yang 
kurang diperhatikan. Selain itu, seorang wirausahawan cenderung memiliki banyak alternatif dalam menyelesaikan suatu permasalahan, wirausahawan cenderung lebih kreatif dan inovatif dalam menciptakan sesuatu yang baru atau produk baru dengan cara yang baru (Karim, 2007). Kemampuan berinovasi terhadap suatu produk merupakan hal terpenting dalam orientasi kewirausahaan. Orientasi kewirausahaan juga berperan dalam pencapaian kesuksesan perusahaan, perusahaan yang berorientasi kewirausahaan akan selalu berusaha menghasilkan produk baru yang inovatif dan memiliki keberanian mengambil risiko, di mana keduanya merupakan indikator orientasi kewirausahaan (Sudarsono, 2015). Galindo, M.A \& Picazo, (2013) menyatakan bahwa orientasi kewirausahaan berpengaruh positif dan signifikan terhadap inovasi perusahaan serta mampu berdampak positif bagi pertumbuhan ekonomi di suatu negara, khususnya negara-negara berkembang. Hal ini serupa dengan hasil penelitian yang dilakukan oleh (Ndubisi, N.O; \& Iftikhar, 2012) yang menyatakan bahwa terdapat hubungan yang signifikan antara proaktif, risiko yang diambil terhadap inovasi, di mana proaktif dan risiko yang diambil (risk taking) merupakan indikator dari orientasi kewirausahaan.

Usaha dalam berinovasi terhadap suatu produk dipercaya mampu meningkatkan kinerja pemasaran (Killa, 2014). Kinerja pemasaran adalah hasil dari keseluruhan baik itu usaha, strategi, maupun kinerja yang telah dijalankan oleh suatu perusahaan (Irawan, 2015). Kinerja pemasaran merupakan faktor yang sering digunakan untuk mengukur sejauh mana prestasi pasar produk yang telah dihasilkan oleh perusahaan. Tiap perusahaan telah menetapkan strateginya masing-masing, perusahaan berusaha menetapkan strategi yang terbaik dan berbeda dari perusahaan lain atau dengan perusahaan pesaing yang menghasilkan produk sejenis. Setiap strategi yang ditetapkan oleh perusahaan mengharapkan kinerja terbaik yang dapat dihasilkan, dalam hal ini adalah kinerja pemasaran. Kinerja pemasaran merupakan hasil dari strategi perusahaan yang telah dicapai perusahaan dalam memenuhi harapan konsumen. Berdasarkan pendahuluan diatas maka kerangka konsep pada penelitian ini adalah sebagai berikut:

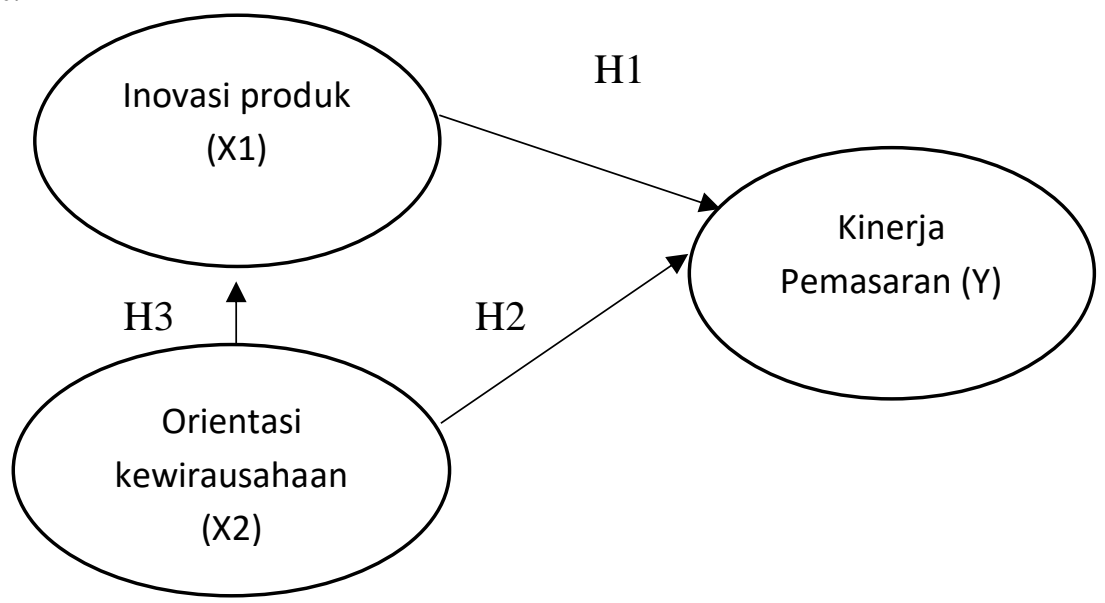

Berdasarkan kerangka konsep terdapat beberapa hipotesis penelitian yakni :

$\mathrm{H} 1$ : Inovasi produk berpengaruh positif signifikan terhadap kinerja pemasaran.

$\mathrm{H} 2$ : Orientasi kewirausahaan berpengaruh positif signifikan terhadap inovasi produk.

H3 : Orientasi kewirausahaan berpengaruh positif signifikan terhadap kinerja pemasaran. 


\section{METODE PENELITIAN}

Penelitian ini dilakukan di Kota Denpasar, karena jumlah industri mikro kecil terbanyak di Provinsi Bali berada pada di Kota Denpasar. Populasi dalam penelitian ini adalah seluruh pemilik usaha industri mikro kecil makanan di Kota Denpasar, dengan sampel sebanyak 100 orang respondengn dengan menggunakan metode non-probability sampling dengan teknik purposive sampling. Metode pengumpulan data dilakukan dengan penyebaran kuesioner dengan menggunakan Skala Likert 5 skor.

Penelitian ini menggunakan teknik analisis jalur (path analysis), Analisis Jalur merupakan perluasan dari analisis Regresi Linear Berganda, untuk menaksir hubungan kausalitas antar variabel yang berjenjang berdasarkan teori. Model Analisis Jalur digunakan untuk menganalisis pola hubungan antar variabel dengan tujuan untuk mengetahui pengaruh langsung dan tidak langsung seperangkat variabel bebas (eksogen) terhadap variabel endogen.

\section{HASIL PENELITIAN}

\section{Karakteristik Responden}

Responden pada penelitian ini berjumlah 100 orang responden yang dikelompokkan berdasarkan usia dan jenis kelamin. Berdasarkan hasi penelitian, usia responden terbanyak berada pada rentang usia > 33 tahun yaitu sebesar 61\%, usia 17-24 tahun sebanyak 11\%, usia 25-32 tahun sebanyak 28\%. Berdasarkan jenis kelamin, responden dengan jenis kelamin perempuan lebih mendominasi pada penelitian ini yakni sebesar $62 \%$ dan jenis kelamin sebesar $38 \%$.

\section{Hasil Analisis Jalur}

Berdasarkan hasil pengolahan data dengan menggunakan analisis jalur, diperoleh hasil pengaruh langsung maupun pengaruh tidak langsung berserta pengaruh total antar variabel yakni sebagai berikut :

\section{Tabel 2. Summary dan Koefisien Jalur 2}

Model Summary

\begin{tabular}{|c|c|c|c|c|}
\hline Model & $\mathrm{R}$ & R Square & Adjusted R Square & $\begin{array}{c}\text { Std. Error of the } \\
\text { Estimate }\end{array}$ \\
\hline 1 & $.854^{\mathrm{a}}$ & .729 & .724 & .52566746 \\
\hline
\end{tabular}

a. Predictors: (Constant), Inovasi Prod., Orientasi Kwu

b. Dependent Variabel: Kinerja pemasaran

ANOVA

\begin{tabular}{|l|r|r|r|r|c|}
\hline Model & $\begin{array}{r}\text { Sum of } \\
\text { Squares }\end{array}$ & \multicolumn{1}{c|}{ df } & Mean Square & F & Sig \\
\hline 1 Regression & 72.196 & 2 & 36.098 & 130.636 & $.000 \mathrm{a}$ \\
$\quad$ Residual & 26.804 & 97 & .276 & & \\
$\quad$ Total & 99.000 & 99 & & & \\
\hline
\end{tabular}

a. Predictors: (Constants), Inovasi Prod., Orientasi Kwu

b. Dependent Variabel: Kinerja Pemasaran 
Coefficients

\begin{tabular}{|c|c|c|c|c|c|}
\hline \multirow[b]{2}{*}{ Model } & \multicolumn{2}{|c|}{$\begin{array}{l}\text { Unstandarized } \\
\text { Coefficients }\end{array}$} & \multirow{2}{*}{$\begin{array}{c}\text { Standarized } \\
\text { Coefficients } \\
\text { Beta }\end{array}$} & \multirow[b]{2}{*}{$\mathrm{t}$} & \multirow[b]{2}{*}{ Sig. } \\
\hline & $\mathrm{B}$ & $\begin{array}{l}\text { Std. } \\
\text { Error }\end{array}$ & & & \\
\hline 1 (Constants) & .000 & .053 & & .000 & 1.000 \\
\hline Kewirausahaan & .526 & .084 & .526 & 6.252 & .000 \\
\hline Inovasi Produk & .378 & .084 & .378 & 4.487 & .000 \\
\hline
\end{tabular}

a. Dependent Variabel: Kinerja Pemasaran

Berdasarkan hasil analisis pengaruh inovasi produk terhadap kinerja pemasaran diperoleh nilai t sebesar 4,487 dengan signifikansi sebesar 0,000 dengan nilai koefisien beta sebesar 0,378. Nilai Sig t 0,000 < 0,05 mengindikasikan bahwa $\mathrm{H}_{0}$ ditolak dan $\mathrm{H}_{1}$ diterima. Hasil ini mempunyai arti bahwa inovasi produk berpengaruh positif dan signifikan terhadap kinerja pemasaran. Berdasarkan hasil analisis pengaruh orientasi kewirausahaan terhadap inovasi produk diperoleh nilai koefisien beta sebesar 0,779, nilai t sebesar 12,282 dengan signifikansi $0,000<0,05$ mengindikasikan bahwa $\mathrm{H}_{0}$ ditolak dan $\mathrm{H}_{1}$ diterima. Hasil ini mempunyai arti bahwa orientasi kewirausahaan berpengaruh positif dan signifikan terhadap inovasi produk. Berdasarkan hasil analisis pengaruh orientasi kewirausahaan terhadap kinerja pemasaran diperoleh nilai koefisien beta sebesar 0,526, nilai $\mathrm{t}$ sebesar 6,252 dengan signifikansi 0,000 0,05 mengindikasikan bahwa $\mathrm{H}_{0}$ ditolak dan $\mathrm{H}_{1}$ diterima. Hasil ini mempunyai arti bahwa orientasi kewirausahaan berpengaruh positif dan signifikan terhadap kinerja pemasaran.

\section{PEMBAHASAN}

\section{Pengaruh Inovasi Produk Terhadap Kinerja Pemasaran}

Berdasarkan hasil penelitian menunjukkan bahwa Hipotesis 1 diterima yakni variabel inovasi produk berpengaruh positif dan signifikan terhadap kinerja pemasaran. Hal ini menunjukkan bahwa semakin sering pelaku usaha industri kecil mikro makanan di Kota Denpasar melakukan inovasi produk maka kinerja pemasarannya akan meningkat. Sebaliknya apabila pelaku usaha industri kecil mikro makanan di Kota Denpasar kurang melakukan inovasi pada produk yang dijualnya maka kinerja pemasarannya pun akan menurun.

Hasil penelitian ini mendukung hasil penelitian-penelitian terdahulu yang dilakukan oleh (Utaminingsih, 2016), (Setiasri, 2017), (Ryiadi; \& Kerti, 2016) bahwa variabel inovasi produk berpengaruh positif signifikan terhadap kinerja pemasaran.

\section{Pengaruh Orientasi Kewirausahaan Terhadap Inovasi Produk}

Berdasarkan hasil penelitian menunjukkan bahwa Hipotesis 2 diterima yakni variabel orientasi kewirausahaan berpengaruh positif dan signifikan terhadap inovasi produk. Hal ini menunjukkan bahwa semakin tinggi orientasi kewirausahaan pelaku usaha industri kecil mikro makanan di Kota Denpasar maka inovasi produknya akan semakin baik. Sebaliknya apabila pelaku usaha industri kecil mikro makanan di Kota Denpasar memiliki orientasi kewirausahaan yang rendah maka inovasi produknya semakin berkurang.

Hasil penelitian ini mendukung hasil penelitian-penelitian terdahulu yang dilakukan oleh (Ryiadi; \& Kerti, 2016), (Helia et.al, 2015), (Helia et.al, 2015) bahwa variabel orientasi kewirausahaan berpengaruh positif signifikan terhadap inovasi produk. 


\section{Pengaruh Orientasi Kewirausahaan Terhadap Kinerja Pemasaran}

Berdasarkan hasil penelitian menunjukkan bahwa Hipotesis 3 diterima yakni variabel orientasi kewirausahaan berpengaruh positif dan signifikan terhadap kinerja pemasaran. Hal ini menunjukkan bahwa semakin tinggi orientasi kewirausahaan pelaku usaha industri kecil mikro makanan di Kota Denpasar maka kinerja pemasarannya akan semakin baik. Sebaliknya apabila pelaku usaha industri kecil mikro makanan di Kota Denpasar memiliki orientasi kewirausahaan yang rendah maka kinerja pemasarannya akan menurun.

Hasil penelitian ini mendukung hasil penelitian-penelitian terdahulu yang dilakukan oleh (Musrifah, 2018), (Jayaningrum, E; \& Brillyanes, 2018), (Ryiadi; \& Kerti, 2016) bahwa variabel orientasi kewirausahaan berpengaruh positif signifikan terhadap kinerja pemasaran.

\section{IMPLIKASI PENELITIAN}

Hasil penelitian ini memberikan implikasi pada pemanfaatan nyata berdasarkan hasil penelitian guna menunjang para pemilik usaha dalam sektor industri khususnya industri mikro kecil makanan untuk terus berkreativitas dalam menginovasi produk makanan yang akan mereka tawarkan pada konsumen, sehingga mempermudah kinerja pemasaran yang akan mempertahankan usaha dari ketatnya persaingan. Selain terus melakukan inovasi pada produk makanannya pemilik usaha pada sektor industri mikro kecil makanan harus siap menanggung risiko serta dapat melihat peluang pasar mengenai makanan seperti apa yang konsumen butuhkan saat ini, agar dapat memenangkan hati konsumen.

\section{KETERBATASAN PENELITIAN}

Penelitian ini memiliki keterbatasan dimana pada penelitian ini lokasi penelitian masih terbatas yakni hanya di Kota Denpasar saja dan hanya mewakili 100 pemiliki usaha pada sektor industri mikro kecil makanan. Serta variabel yang mendukung kinerja pemasaran yang diteliti hanya menggunakan variabel inovasi produk serta orientasi kewirausahaan saja.

\section{SIMPULAN DAN SARAN}

Berdasarkan dari hasil penelitian yang telah dipaparkan diatas maka dapat disimpulkan bahwa inovasi produk berpengaruh positif signifikan terhadap kinerja pemasaran, orientasi kewirausahaan berpengaruh positif signifikan terhadap inovasi produk, dan orientasi kewirausahaan berpengaruh positif signifikan terhadap kinerja pemasaran.

Berdasarkan hasil, pembahasan dan kesimpulan penelitian ini, maka terdapat beberapa saran untuk para pelaku usaha industri mikro kecil makanan di Kota Denpasar untuk terus melakukan inovasi pada makanannya, serta meningkatkan kemampuan berwirausahaanya agar dapat memenangkan persaingan yang ketat.

Bagi penelitian dimasa mendatang diharapkan memperluas jangkauan responden serta menambahkan variabel lain terkait kinerja pemasaran diluar variabel inovasi produk dan orientasi kewirausahaan.

\section{DAFTAR PUSTAKA}

\section{Alarape, A. A. (2013). Entrepreneurial Orientation and The Growth Performance of Small and Medium Enterprises in Southwestern Nigeria. Journal of Small Business Dan Entrepreneurship, 26(6), 553-577. \\ Djojobo, C.V \& Tawas, H. . (2014). Pengaruh orientasi Kewirausahaan, Inovasi Produk, dan Keunggulan Bersaing terhadap Kinerja Pemasaran Usaha Nasi Kuning di Kota Manado. .. Jurnal EMBA, 2(3), 1214-1224.}


Galindo, M.A \& Picazo, M. T. (2013). Galindo, Innovation, Entrepreneurship and Economic Growth. Journal of Management Decision, 51(3), 501-514.

Helia, R., Naili, F., \& Bulan, P. (2015). No Title. Pengaruh Orientasi Pasar Dan Orientasi

Kewirausahaan Terhadap Keunggulan Bersaing Melalui Inovasi Produk Sebagai Variabel Antara (Studi Kasus Pada IKM Batik Di Kampung Batik Laweyan, Solo).

Irawan, B. . (2015). Dampak Inovasi Produk terhadap Kinerja Pemasaran. Jurnal AGORA, 3(1), 127-137.

Jayaningrum, E; \& Brillyanes, S. (2018). Pengaruh Orientasi Pasar, Inovasi, Orientasi Kewirausahaan Terhadap Keunggulan Bersaing dan Kinerja Pemasaran. Jurnal Administrasi Bisnis (JAB), 54 (1).

Killa, M. . (2014). Effect of Entrepreneurial Innovativeness Orientation, Product Innovation, and Value Co- Creation on Marketing Performance. Journal of Research in Marketing, 2(3), 198-204.

Kotler., K. (2008). Manajemen Pemasaran. Erlangga.

Musrifah. (2018). Pengaruh Orientasi Pasar dan Orientasi Kewirausahaan terhadap Kinerja Pemasaran melalui Keunggulan Bersaing. Management Analysis Journal, 6(4).

Ndubisi, N.O; \& Iftikhar, K. (2012). Relationship between Entrepreneurship, Innovation and Performance. Journal in Research in Marketing and Entepreneurship, 14(2), 214-236.

Ryiadi; \& Kerti, Y. (2016). Kemampuan Inovasi Memediasi Pengaruh Orientasi

Kewirausahaan Terhadap Kinerja Produk IMK Sektor Industri Makanan di Kota

Denpasar. E-Jurnal Manajemen Unud, 5(3).

Setiasri, R. . (2017). Pengaruh Inovasi Produk dan Network Capital Terhadap Kinerja Pemasaran IKM Batik Kampung Batik Pesindon Kota Pekalongan. Diponogoro University Journal of Social and Politic, Business Administration.

Sudarsono, B. (2015). Analisis Pengaruh Orientasi Kewirausahaan terhadap Strategi Bisnis dalam Meningkatkan Kinerja Usaha Kecil dan Menengah (UKM). Jurnal ORBITH, 11(1), 24-29.

Sudaryanto; Ragimun; \& Wijayanti, R. . (2013). Strategi Pemberdayaan UMKM Menghadapi Pasar Bebas ASEAN. E-Jurnal Syarif Hidayatullah State Islamic University (UIN) Jakarta.

Utaminingsih, A. (2016). Pengaruh Orientasi Pasar, Inovasi Dan Kreativitas Strategi Pemasaran Terhadap Kinerja Pemasaran Pada Ukm Kerajinan Rotan Di Desa Teluk Wetan, Welahan, Jepara. Media Ekonomi Dan Manajemen, 31(2).

Wardoyo, P. R. E. \& P. S. (2015). Pengaruh Orientasi Kewirausahaan terhadap Strategi Usaha dan Kinerja Bisnis UMKM di Desa Ujung- Ujung, kec. Pabelan, Kab. Semarang. Journal \& Proceeding Feb UNSOED, 5(1). 